\title{
Socioeconomic school segregation in Chile: parental choice and a theoretical counterfactual analysis
}

\author{
Humberto Santos and Gregory Elacqua
}

ABSTRACT

In this article, we examine the hypothesis that the policy of parental school choice in Chile has increased socioeconomic school segregation. We use a georeferenced database of students and schools in the Greater Metropolitan Area of Santiago to compare actual segregation with the segregation that would occur in the hypothetical case that students attended the school nearest to their place of residence. The results indicate that school segregation is higher in the actual scenario than in the counterfactual scenario, which suggests that the interaction between family preferences and school entry barriers (tuition and selective admission process) tend to increase school segregation beyond the city's underlying residential segregation. of Diego Portales University in Santiago, Chile. hsantos@iadb.org

Gregory Elacqua is director of the Public Policy Institute of the Faculty of Economics and Business of Diego Portales University in Santiago, Chile. gregorye@iadb.org 


\section{I}

\section{Introduction}

In 1981, the Chilean school system underwent a structural reform enacted by the military regime (1973-1989). First, the government decentralized the administration of public schools, transferring their management from the central government to municipalities. Second, it changed the funding formula for public and private schools. Public schools continued to receive funding from the central government, but municipalities were now paid a subsidy (voucher) for each student enrolled in their schools. Private schools - non-profit and forprofit - that did not charge tuition fees received the same per-pupil subsidy for every student as public schools. These policies were introduced as a way to increase the autonomy of public schools and promote efficiency by encouraging competition to attract larger numbers of students.

The essential components of the universal system of school choice have remained in place for over three decades. The only significant changes to the rules under which the voucher programme operates were introduced in 1994, when the government enacted a law allowing private voucher schools and public high schools to charge limited tuition, and in 2008 when the government banned primary schools from using parental interviews as part of admissions procedures. Also in 2008, the government introduced an additional voucher $(50 \%$ over the base voucher) for students classified as disadvantaged by the Ministry of Education. These modifications were meant to improve the design of the vouchers programme by providing schools with incentives to attract a diverse student body and providing parents with more access to a diverse set of schooling options and objective information on schools.

There is an extensive body of literature in Chile that has explored the effects of the country's national voucher programme on student achievement (see, for example, Auguste and Valenzuela, 2004; Gallego, 2002; Hsieh and Urquiola, 2006). However, the question of whether school choice has an effect on socioeconomic segregation (SES) has been addressed only recently (for example, Bellei, De los Ríos and Valenzuela, 2014; Elacqua, 2012). This issue has emerged as a concern for two main reasons. First, there is evidence to suggest that the Chilean school system has one of the highest levels of socioeconomic school segregation among the countries participating in the Programme for International Student Assessment (PISA) (OECD, 2011). Second, a considerable body of international literature shows that school segregation has adverse effects on different outcomes, such as educational achievement (Hanushek, Kain and Rivkin, 2009; Hoxby, 2002; Kahlenberg, 2001; Zimmer and Toma, 2000), adolescent pregnancy, the probability of school dropout (Guryan, 2004), the educational environment at the school (Hanushek and others, 2004), non-cognitive outcomes such as intellectual engagement and motivation (Crain and Strauss, 1985; Rothstein, 2004; Wells and others, 2008), and civic engagement indices (Levinson and Levinson, 2003). Although there is relative consensus about the high levels of school segregation and its negative effects, there is less agreement about the extent to which Chile's national voucher programme contributes to this outcome. On the one hand, critics argue that the interaction between the preferences exercised by families and the entry barriers erected by schools tends to increase school segregation (Bellei, De los Ríos and Valenzuela, 2014). On the other hand, proponents assert that school segregation is explained mainly by Chile's unequal income distribution and the high levels of residential segregation typical of its cities and neighbourhoods (Beyer and Eyzaguirre, 2014).

To advance this debate, we have constructed a unique data set using georeferenced information on the students and schools in the Greater Metropolitan Area of Santiago to study the effect of school choice on socioeconomic segregation. Specifically, in this article we compare actual school segregation with the level of segregation that would occur in the hypothetical case that students attended the school closest to their place of residence. If school choice and other structural components of the system (as opposed to residential segregation) are the driving force behind school segregation, then actual school segregation should be greater than school segregation in the hypothetical (non-choice) scenario. One of the most interesting features of the Chilean case is the co-existence of different types of education providers, which allows researchers to analyse differences in the behaviour of public, for-profit and non-profit private voucher schools. There is limited evidence on this point, because most school systems do not provide public funding to for- 
profit schools. In most countries, schools continue to be funded and managed primarily by the government, and private schools are usually required to have non-profit status (Elacqua, 2012; James, 1993).

This article is organized in sections, including the Introduction. The second section presents a literature review on the effects of school choice on segregation in Chile. Section III describes the methodology for the study. Section IV presents the data used and section V discusses the main findings. Lastly, section VI offers conclusions and discusses the study's implications for public policy.

\section{II}

\section{Literature review}

Voucher advocates argue that, given the high levels of residential segregation in most cities, school choice can reduce school segregation by providing low-income parents with access to more integrated schools outside their neighbourhoods (Moe, 2001). Some have also argued that since parents may have more objective information about school quality (e.g. standardized test scores) than about neighbourhood quality, school choice may depend less on family sociodemographic profiles than the choice of neighbourhood in which to live (Krysan, 2002). As a result, advocates maintain that voucher policies are more effective than traditional proximity assignment programmes at reducing socioeconomic school segregation. ${ }^{1}$

Critics of school choice have cited education service demand and supply factors that can influence the concentration of students from similar socioeconomic levels within schools. On the demand side, sceptics maintain that a school's social composition is an attribute valued by families. For example, Elacqua, Buckley and Schneider (2006) find that families in Santiago are more likely to choose a school on the basis of its socioeconomic composition than objective indicators of academic performance. However, if family assessment of school attributes varies according to their own characteristics, then students from different socioeconomic levels will not choose to attend the same type of school. For example, Gallego and Hernando (2009) find that, in choosing a school, higher-income families afford less importance to distance than other families, and more importance to academic quality (measured by test score results). Lastly, there is concern that parents of lower socioeconomic status do not have the resources to choose their children's school (e.g. information about available alternatives,

\footnotetext{
${ }^{1}$ For a discussion of the factors that influence school and neighborhood choices, see Bifulco, Ladd and Ross (2009).
}

networks, time, the ability to process the information, and so forth). Elacqua and Fábrega (2004), for example, find that parents with a low level of education are more likely to form their opinions based on information they receive from their social networks (family, neighbours, friends, church members, colleagues and neighbourhood associations) compared with parents with a higher level of education. However, the quality of their networks - measured by the members' level of education- is low compared with those of higher-income parents.

On the supply side, voucher critics argue that competition leads some schools to select more advantaged students who are less costly to educate. For instance, Hsieh and Urquiola (2006) find that the flat voucher introduced in Chile in 1981 led to an increase in school stratification, mainly through the exodus of middle-class students from public schools into the private voucher schools. $^{2}$ One of the major effects of the 1981 reform was to diversify the supply of private schools, especially through the emergence of for-profit suppliers, a sector that today accounts for a third of total enrolments (Elacqua, Martínez and Santos, 2015).

There is a heated debate on for-profit schooling. The main argument in favour of these schools is that the profit motive requires them to focus on the client, leading to a better balance between parent preferences and school mission. Although a diversity of alternatives is fundamental to a school choice system, critics claim that this differentiation reduces the integration of students from distinct social and cultural origins (Bellei, 2010). Critics have argued that since for-profit schools are oriented towards gaining economic rents, they will try to

\footnotetext{
2 The preferential school subsidy (SEP), introduced in 2008, changed the incentives for schools. It introduced an additional subsidy for vulnerable students and prohibited schools from collecting fees from these students. The General Education Law (LGE), also enacted in 2008, banned selection practices in primary grades (first to sixth grade).
} 
cut costs by targeting students who are more advantaged and less expensive to educate (Levin, 2002). Some scholars have also argued that non-profit schools, which enrol approximately $15 \%$ of the student body in Chile, are better positioned to serve disadvantaged students than for-profit schools because they are often able to rely on grants and lower labour costs (such as volunteers) to finance the large investment involved in educating lowincome students (Rose-Ackerman, 1996). Only recently have studies begun to analyse behavioural differences between the various types of private providers in the Chilean education system. For example, Elacqua (2012) shows that, contrary to expectations, for-profit schools enrol a higher percentage of low-income students than non-profit schools. Nonetheless, school segregation is higher within the for-profit sector, which suggests that these schools seek market niches in different socioeconomic groups.

There are two mechanisms that Chilean schools can use to shape their student bodies: charging school fees and screening students. The main argument against charging school fees is that mandatory tuition would segment the private voucher sector based on family ability-to-pay. In fact, Bellei, De los Ríos and Valenzuela (2014) find that, on average, the larger the number of feepaying schools in a neighbourhood, the higher the level of socioeconomic segregation in that neighbourhood's schools. Elacqua (2012) shows that schools that charge tuition enrol a smaller proportion of low-income students than free private voucher schools and public schools. This study also finds that the private voucher school sector that charges tuition is more internally segregated than the public sector and the free private voucher school sector. However, other researchers question these results. For example, Gallego and Hernando (2008) argue that

\section{III}

\section{Methodology}

The empirical strategy of this article is based on two principal components. First, we define the concept of segregation and analyse the various indices used to measure it, which are derived from the literature developed to study residential and school segregation among racial minorities (Duncan and Duncan, 1955; James and Taeuber, 1985; Massey and Denton, 1988; White, 1986; Zoloth, 1976). Second, we present the segregation can be better explained by factors associated with family preferences and that banning tuition fees would have only moderate effects on school segregation.

Regarding the school admission process in Chile, the evidence suggests that although the General Education Law (LGE) prohibits selection in primary grades, many schools still conduct interviews with parents and require them to provide proof of income and affinity with certain religious beliefs (e.g. christening or religious marriage certificates), especially in the private voucher sector. Many schools also require students to sit entrance exams (Bustos, Contreras and Sepúlveda, 2010; Carrasco and others, 2014; Elacqua, Martínez and Santos, 2011).

In addition to factors directly related to supply and demand, in most school systems - regardless of the degree of parental choice - residential segregation in cities is linked to school segregation. In the case of Chile, there is evidence that a significant percentage of parents tend to choose schools close to where they live —especially pre-primary and primary schoolwhich creates a direct relationship between the social makeup of the neighbourhood and that of the school. For instance, Alves and others (2012) find that 70\% of fourth-grade students enrolled in public and private voucher schools in the Greater Metropolitan Area of Santiago travel less than $1.5 \mathrm{~km}$ to get to school. Thus, some have concluded that residential segregation is the main driver of increased school segregation (Beyer and Eyzaguirre, 2014; El Mercurio, 2013).

In this paper, we examine the hypothesis that the policy of parental school choice has increased socioeconomic segregation in Chile, by comparing actual segregation with the hypothetical segregation that would occur if students attended the school closest to where they live. design of the counterfactual scenario and the assumptions on which it is based.

\section{Segregation indices}

In very general terms, segregation is the degree to which two or more groups are isolated from each other within a certain geographical space. According to Massey and 
Denton (1988), there are five dimensions by which different groups can be segregated: evenness, exposure, concentration, centralization and clustering. Of these dimensions, evenness and exposure have been more methodologically resolved in the literature, and there are various alternative indices for each measure.

First, we used the two-group (Duncan and Duncan, 1955) and multigroup (Reardon and Firebaugh, 2002) versions of the dissimilarity index or Duncan index $(D)$. Assuming two groups, ${ }^{3}$ one defined as the minority group (e.g. socioeconomically disadvantaged students or students belonging to an ethnic group) and the other as the majority group (rest of students), and defining $T$ and $P$ as the total population size and proportion of the minority group in the city, respectively, with $t_{i}$ and $p_{i}$ denoting the same values for school $i$, this index is mathematically defined as:

$$
D=\sum t_{i}\left|p_{i}-P\right| / 2 T P(1-P)
$$

where $D$ is the weighted average deviation of the proportion of minority students in each school from $P$, expressed as a fraction of its maximum. Therefore, $D$ is a value between 0 (no segregation) and 1 (complete segregation). $D$ can be interpreted as the proportion of all students in either group to be transferred so that $p_{i}$ is equal to $P$ for all $i$, or in other words, for every school in the city to have the same social composition (Duncan and Duncan, 1955).

Second, we use the exposure index $(X)$, which is defined as:

$$
E=\sum t_{i}\left(1-p_{i}\right) / T
$$

where $T$ is the total number of minority students in the city and $t_{i}$ and $p_{i}$ are the number and proportion of students belonging to minority groups in school $i$. The index can be interpreted as the percentage of students from the majority group that exists in the average school attended by a minority student. Unlike the Duncan index, this index depends on the relative size of the groups, which implies that it is sensitive to the definition of minority group and thus is not symmetrical (i.e. the

\footnotetext{
${ }^{3}$ The mathematical expression for the multigroup dissimilarity index can be found in Reardon and Firebaugh (2002). Interpretation of this index is similar to that of the two-group version. The difference is that in this case the distribution is in $\mathrm{n}$ groups, instead of dividing the population into two mutually exclusive categories.
}

index does not necessarily have the same value for the minority and majority groups).

We use the Duncan index because it meets the key criteria for a segregation index (James and Taeuber, 1985), insofar it is widely used in the empirical literature and because it has a direct interpretation, facilitating comparison with national and international studies. We use the exposure index because it is simpler to interpret, which facilitates analysis of our results. Although there are other segregation indices used in the literature that fulfil more stringent properties, they are generally not simple to interpret and are used mainly for comparisons over time and between cities (Reardon and Firebaugh, 2002).

\section{The design of the counterfactual scenario}

There are several studies that compare the observed level of school segregation with the level simulated in different counterfactual scenarios in which all students attend the public school to which they are geographically assigned (Bifulco, Ladd and Ross, 2009, for the school district of Durham, North Carolina; Sohoni and Saporito, 2009, for the 22 largest school districts in the United States; Riedel and others, 2010, for the city of Wuppertal, Germany) or the school closest to their place of residence (Allen, 2007, for England; Östh, Andersson and Malmberg, 2013, for Sweden), using available georeferenced information on schools and families. Although they analyse systems with different degrees of school choice, all five studies show that the level of school segregation by race, ethnicity, socioeconomic level and/or ability is greater in the actual scenario - i.e. where families can choose a school different from the one assigned to them or the one closest to their place of residence - than in the counterfactual scenario. Thus, they conclude that school choice exacerbates school segregation.

We employ a method similar to the one used by Allen (2007), who simulates a counterfactual scenario where students attend the school closest to their place of residence. The level of school segregation in this case is explained entirely by the geographical distribution of students from different socioeconomic levels within the city (residential segregation) and by school location. The difference between this segregation level and the actual level is what Allen (2007) terms post-residential segregation, because it measures the additional effect of the choices of families who send their children to a school other than the one closest to their residence, whether by their own decision or because that school is not accessible to the student. 
We acknowledge that this counterfactual may not be exactly what would occur in the absence of a school choice policy. First, it assumes that families cannot change their place of residence. Yet there is evidence that the decision of where to live depends on the available educational supply. ${ }^{4}$ Hence, in a hypothetical scenario where students must attend the closest school, one would

${ }^{4}$ For example, researchers have consistently found that public school performance has a significant impact on housing prices in school systems where students are assigned to schools based on their place of residence (Black, 1999; Bayer, Ferreira and McMillan, 2007; Reback, 2005, for the United States; Gibbons and Machin, 2003 and 2006, for the United Kingdom; and Fack and Grenet, 2010, for France). expect, at least in the long term, greater residential mobility among parents seeking access to the schools that best match their preferences. Since a change of residence is costly, this choice mechanism would be available mainly to high-income families, which would increase levels of residential and school segregation. Second, the counterfactual assumes that schools do not use any kind of selection mechanism and, therefore, that the distribution of students is based exclusively on place of residence. Third, it assumes that there are no new schools and that existing schools remain within the system. Finally, the counterfactual analyses do not consider school capacity restrictions given their current facilities.

\section{IV Data}

Our empirical analysis uses data on fourth-grade students in the Greater Metropolitan Area of Santiago during the 2010 school year. The data are drawn from four sources. First, the national standardized test (SIMCE) parent survey contains information on the student's socioeconomic level, including the highest level of education obtained by the student's parents. ${ }^{5}$ Second, the General Student Information System (SIGE) of the Ministry of Education (MINEDUC) includes an address for most public and private voucher school students. ${ }^{6}$ Third, MINEDUC administrative information contains information on the school characteristics, including ownership type (forprofit, non-profit) and tuition fees. Finally, the MINEDUC website carries an address for every preschool, primary school and secondary school in Chile. ${ }^{7}$

\footnotetext{
5 According to data from fourth-grade sIMCE 2010, 95.2\% of households returned the questionnaire to the school. To test whether there are significant differences between students with and without information, we compared the 2010 fourth-grade SIMCE test score in reading, mathematics and history and the socioeconomic level of the school of attendance for both groups. The results indicated that, on average, students with questionnaires scored 10 points higher in reading, 8.5 points higher in mathematics, and 8.5 points higher in history than those without questionnaires. However, we also found that students whose households did not return the questionnaires tended to go to lower-socioeconomic schools. Both results indicate that low-SES students are slightly underrepresented in the sample.

${ }^{6}$ Our database does not contain any other personal data that would reveal a student's identity (e.g. name and ID number).

7 The database in .kmz format (Google Earth) is available at http:// www.mineduc.cl.
}

The target population consisted of students attending public and private voucher schools in the Greater Metropolitan Area of Santiago $(69,014)$. From this universe, we were able to georeference the addresses of 31,645 students $(46 \%) .{ }^{8}$ The majority of students without addresses were cases where the SIGE database showed the address field as empty, while a smaller percentage corresponded to addresses that could not be located. ${ }^{9}$ After eliminating a group of students whose place of residence was outside the Greater Metropolitan Area of Santiago, we had a sample of 31,371 students distributed among 1,240 schools. Using the coordinates of the place of residence of each student and the coordinates of all schools in Santiago, we were able to determine the nearest

\footnotetext{
8 Private non-voucher schools were not considered due to the low percentage of students with address data. The normalization, validation and geocodification (obtaining the geographical coordinates) of the addresses was done by Infomatic (http://www.infomatic.cl/).

${ }^{9}$ One weakness of SIGE is that there is no precise information about the process of collecting addresses within each school because it is not mandatory to collect this information. In order to determine if there was any bias in the sample of students with coordinates, we calculated means difference tests for the parents' years of schooling, household income, SIMCE results and household size for students with and without coordinates. The results indicate that the differences, although significant in some cases, are of a very low magnitude. In order to see the results by school, we calculated the mother's average years of schooling by school, first using the sample with coordinates and then using the total student population. In $80 \%$ of schools, the difference between these figures is greater than -1 (the sample underestimates the mother's average years of schooling by less than a year) and less than 1 (the sample overestimates the mother's average years of schooling by less than a year).
} 
school for each student, which we used to construct the counterfactual scenario. We used the information on the school actually attended by each student to build the actual segregation indices for this same sample.

Each student's socioeconomic status (SES) was determined by the highest level of education obtained by either of the student's parents. ${ }^{10}$ Based on that information, the students were then classified into three categories: low socioeconomic status (low-SES), for less than 12 years of education or incomplete high school education; middle socioeconomic status (middle-SES) for 12 years of education or high school graduates; and high socioeconomic status (high-SEs) for over 12 years of education or tertiary education, whether complete or incomplete.

Schools were classified by two criteria. First, they were divided into three categories based on ownership type: (i) public; (ii) for-profit voucher, and (iii) nonprofit voucher. ${ }^{11}$ Second, schools were divided into four categories based on the entry barriers that they establish for families: (i) low price and low selectivity; (ii) high price and low selectivity; (iii) low price and high selectivity, and (iv) high price and high selectivity. A school was considered low-price when the monthly tuition charged

10 That is, either the father's years of schooling or the mother's years of schooling. Parents' schooling has been widely used in other research to construct indicators of students' socioeconomic status. For a review of various definitions, see Sirin (2005).

11 The for-profit owners include individuals and legal entities. In the latter case, this may be a public limited company, a limited liability company or an individual limited liability company. Meanwhile, non-profit owners include organizations such as foundations, religious congregations, trade associations, unions, neighbourhood associations, community organizations and cooperatives. during the 2009 school year was US\$ 15 or less. ${ }^{12}$ A school was considered to be low-selectivity when fell within the first seven deciles of an index constructed from information about the requirements and records that parents must present when applying for enrolment, which was obtained from the national standardized test (SIMCE) fourth-grade parent survey. ${ }^{13}$ Table 1 presents the descriptive statistics of the final sample.

TABLE 1

\section{Descriptive statistics of the final sample} (Percentages)

\begin{tabular}{ll}
\hline Student socioeconomic status & \\
Low & 25.1 \\
Middle & 39.6 \\
High & 35.3 \\
\hline School ownership types & \\
Public & 35.1 \\
Private for-profit voucher & 46.6 \\
Private non-profit voucher & 18.4 \\
\hline Entry barriers & \\
Low price/low selectivity & 52.8 \\
High price/low selectivity & 13.6 \\
Low price/high selectivity & 11.5 \\
High price/high selectivity & 22.1 \\
\hline Attend the nearest school & 19.1 \\
\hline
\end{tabular}

Source: Prepared by the authors.

12 Schools that charge up to US\$ 15 are equivalent to free schools since they do not have any discounts applied to the per student voucher. ${ }^{13}$ Using principal components analysis, we calculated an index that combines five variables, which correspond to the percentage of parents who said they had been required to: (i) present a christening and/or religious marriage certificate; (ii) present report cards from the previous school; (iii) present a salary statement; (iv) attend an interview, and (v) have their child take an entrance exam.

\section{Results}

The results are presented in four subsections. In the first one, we compare various segregation indices in the actual scenario versus the counterfactual scenario. In the two following subsections, we compute the segregation level between school sectors (i.e. differences in the proportion of students of different socioeconomic status that enrol in each school type) and within each sector (i.e. differences in student distribution within each school type) in each scenario. Finally, the last subsection explores the extent to which entry barriers - tuition and school selectioninfluence the outcomes.

\section{Segregation in actual versus counterfactual scenarios}

Table 2 shows a comparison between different indices of socioeconomic segregation in the actual and counterfactual scenarios. What is evident from this table 
is that socioeconomic segregation among students of low socioeconomic status is lower in the counterfactual scenario, given that the dissimilarity index between this category of students and the rest falls by 12 points (from 0.481 to 0.360$).{ }^{14}$ In terms of exposure, this implies that the average student of low socioeconomic status attends a school where $56 \%$ of his or her peers are of middle or high socioeconomic status, despite the fact that in the entire Greater Metropolitan Area of Santiago 75\% of students belong to one of these two groups (see table 1). When the distribution is based exclusively on the student's place of residence, exposure increases to $64.4 \%$.

Considering the results of the indices that compare the groups (low-SES/middle-SES, low-SES/high-SES, and middle-SES/high-SES), we observe that the largest effect is in the distribution of the two extreme groups (low-SES and high-SES). In this case, the Duncan index falls by almost 15 points (from 0.657 to 0.511 ). However, interestingly, the Duncan index for the low-SES and high-SES group has a value of 0.511 in the counterfactual scenario, which means that the level of residential segregation is high in both groups.

Finally, the multigroup Duncan index shows a smaller decline than the low-SEs/rest Duncan index ( 9 points) because it considers the distribution of all three groups simultaneously. In this case, the Duncan index falls from 0.417 to 0.332 . This suggests that middle-SES and high-SES students may be less concentrated than low-SES students.

These results suggest that schools are more segregated than neighbourhoods. The findings are consistent with those reported by Bellei, De los Ríos and Valenzuela (2014) using a different methodology and data. In the following two subsections, we show that the lower level of school segregation in the counterfactual scenario is explained by lower levels of segregation both between and within different school types.

\footnotetext{
${ }^{14}$ In order to analyse the indices' sensitivity to our sample of students, we compared the value from table 2 for the Duncan index for the lowSES/rest group in the actual scenario ( 0.481$)$ with the index constructed from the full student population (with and without coordinates). The value of the index in this case was 0.46 . These results are available upon request.
}

TABLE 2

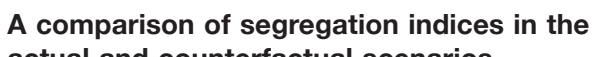
actual and counterfactual scenarios

\begin{tabular}{llc}
\hline Segregation index & $\begin{array}{c}\text { Actual } \\
\text { situation }\end{array}$ & $\begin{array}{c}\text { Counterfactual: all students } \\
\text { attend the } \\
\text { their place of residence }\end{array}$ \\
\hline Low-SEs/rest & & 0.360 \\
\hline Dissimilarity index $(D)$ & 0.481 & 0.644 \\
Exposure index $(X)$ & 0.564 & 0.274 \\
\hline Low-SEs/middle-SES & & 0.544 \\
\hline Dissimilarity index $(D)$ & 0.362 & 0.511 \\
Exposure index $(X)$ & 0.501 & 0.389 \\
\hline Low-SES/high-SES & & \\
\hline Dissimilarity index $(D)$ & 0.657 & 0.379 \\
Exposure index $(X)$ & 0.282 & 0.372 \\
\hline Middle-SES/high-SES & & 0.332 \\
\hline Dissimilarity index $(D)$ & 0.445 & \\
Exposure index $(X)$ & 0.339 & \\
\hline Multigroup & & \\
\hline Duncan index $(D)$ & 0.417 & \\
\hline Source: Prepared by & & \\
\hline
\end{tabular}

Source: Prepared by the authors.

\section{Segregation between sectors in the actual and counterfactual scenarios}

Consistently with most of the previous literature, figure 1 illustrates that the public sector currently enrols a greater percentage of low-SES students and a smaller percentage of high-SES students than does the private voucher school sector. Yet, within the private sector, the for-profit sector enrols a greater percentage of low-SES and middle-SES students and a smaller percentage of high-SES students than the non-profit sector. These results are consistent with those presented in Elacqua (2012).

Under the counterfactual scenario, where students attend the school closest to their residence, in the public sector, the percentage of high-SES students would increase by 10 points (from $19.9 \%$ to $29.9 \%$ ) and the percentage of low-SEs students would decline by 10 points (from $40.0 \%$ to $29.3 \%$ ). By contrast, in the non-profit sector, the percentage of low-SES students would increase by 11 points (from $15.2 \%$ to $26.2 \%$ ) and the percentage of high-SES students would decrease by 16 points (from $50.2 \%$ to $34.3 \%$ ). The changes are less pronounced in the for-profit sector. 
These findings suggest that in the public and non-profit sectors, schools systematically tend to enrol a student body that does not mirror the social composition of the neighbourhood where they are located. They either enrol students with a lower sEs than that of the neighbourhood (public schools) or they enrol students with a higher sEs than that of the neighbourhood (non-profit schools). The fact that the social composition of schools in the for-profit sector does not change significantly between the two scenarios suggests greater heterogeneity within this sector.

FIGURE 1

Enrolment distribution in actual and counterfactual scenarios by school type (Percentages)

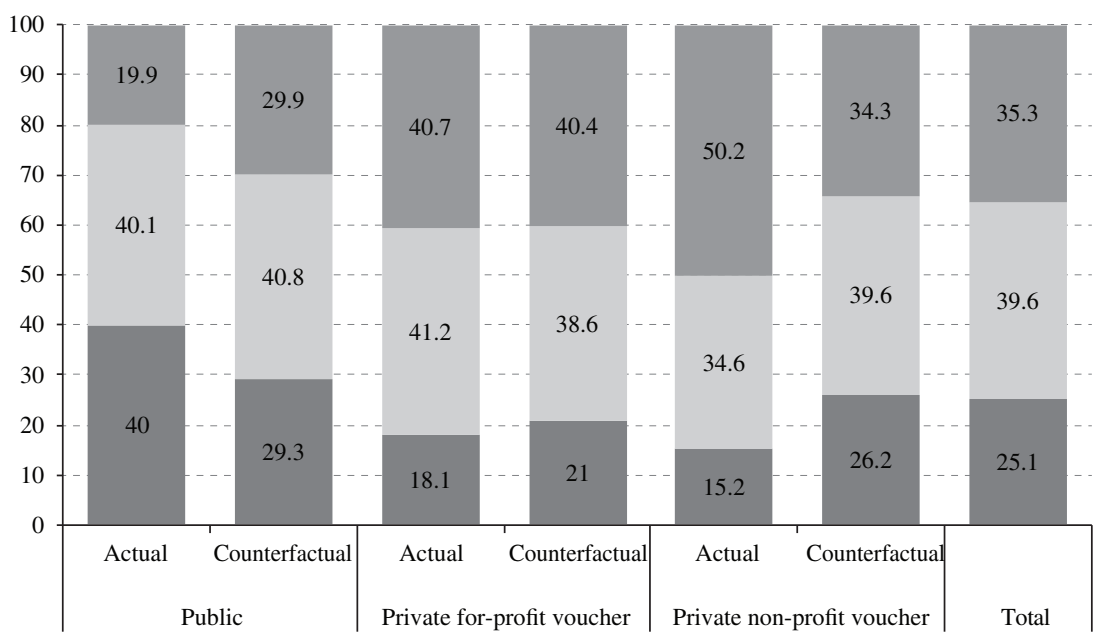

Low socioeconomic status

Middle socioeconomic status

High socioeconomic status

Source: Prepared by the authors.

\section{Segregation within sectors in the actual and counterfactual scenarios}

Figure 2 shows that the public sector is currently the least segregated in terms of socioeconomic status, while the non-profit sector is the most segregated.

Socioeconomic segregation declines under the counterfactual scenario in all sectors, but the effect is greater among private voucher schools, especially in the non-profit sector. The interpretation of these changes is interesting. Under the counterfactual scenario, the distribution of students from different SES groups within each sector depends on residential segregation and the geographic location of the schools. Therefore, the level of segregation that persists under this scenario is explained by the fact that schools are located in neighbourhoods with different social compositions. The higher level of actual segregation in relation to the level in the counterfactual scenario suggests that the preferences exercised by parents and the entry barriers instituted by schools increase the concentration of students from similar socioeconomic levels beyond what can be explained by the schools' choice of location, especially in the non-profit sector. 
FIGURE 2

Dissimilarity index in actual and counterfactual scenarios by school type

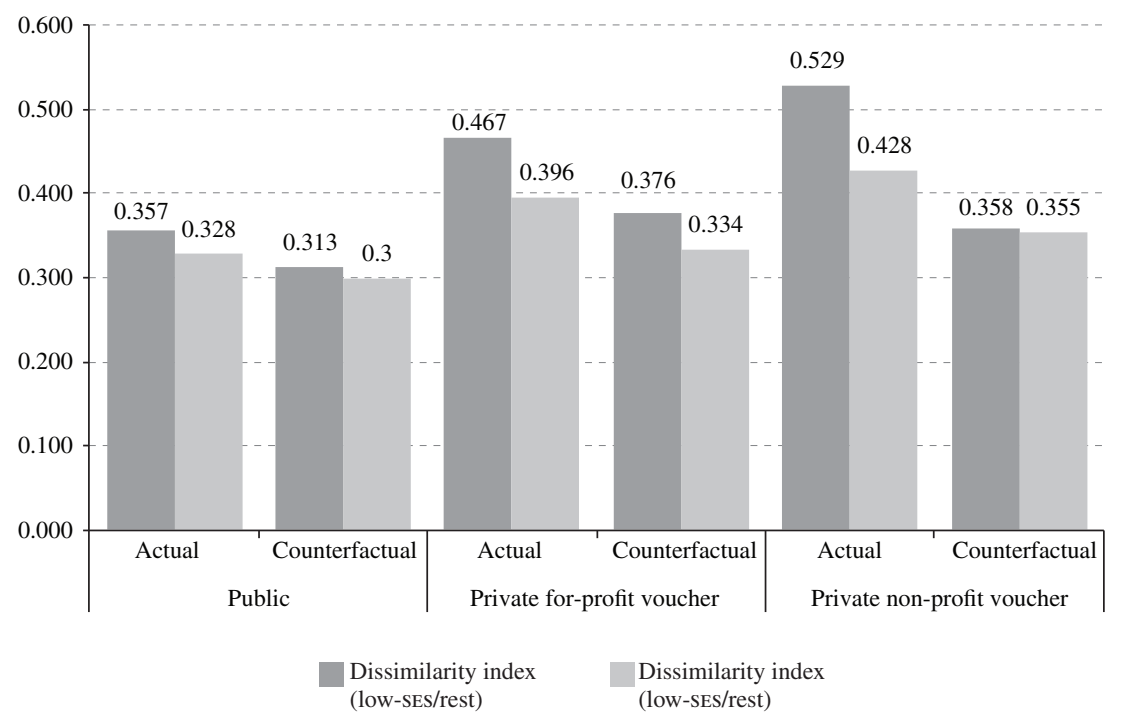

Source: Prepared by the authors.

\section{The role of entry barriers}

In order to explore how these results are related to the entry barriers that schools establish, this subsection categorizes schools by the amount of tuition they charge and the requirements they make of families during the admission process. Figure 3 shows the distribution of schools within each sector according to entry barriers. It illustrates that the public sector has the lowest barriers to entry, while the non-profit voucher sector has the highest. Within the for-profit sector, we observe more heterogeneity.

To analyse how the heterogeneity within the forprofit sector influences school segregation, in figure 4 we compare the socioeconomic composition of schools in the actual and counterfactual scenarios. The $\mathrm{x}$-axis corresponds to the percentage of low-SES students who would enrol in the school in the counterfactual scenario, and the $y$-axis corresponds to the percentage of lowSES students actually enrolled in the school. The $45^{\circ}$ line represents the point at which these proportions are equal. ${ }^{15}$ In order to avoid extreme values, this analysis is limited to those schools that have more than ten students in both scenarios. ${ }^{16}$

\footnotetext{
15 If all schools were above the $45^{\circ}$ line, then actual and counterfactual segregation would be the same.

16 When we apply this restriction, $62.4 \%$ of the total student sample remains.
} 
FIGURE 3

School type and entry barriers

(Percentages)

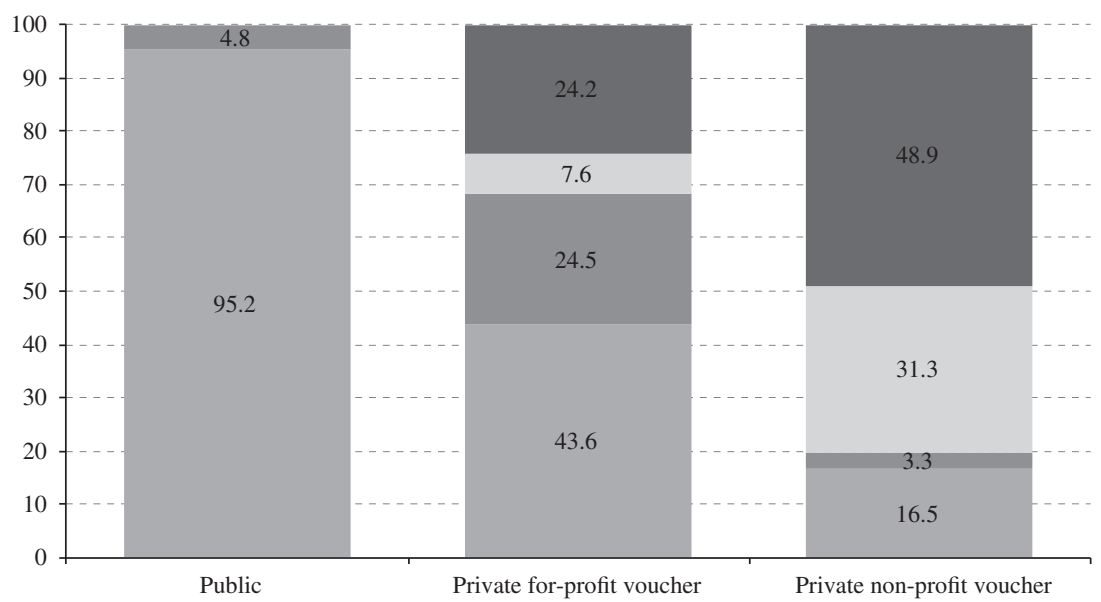

Low price, low selectivity

High price, low selectivity

Low price, high selectivity

High price, high selectivity

Source: Prepared by the authors.

FIGURE 4

For-profit voucher school socioeconomic composition in actual versus counterfactual scenarios, grouped by entry barriers

(Percentages)

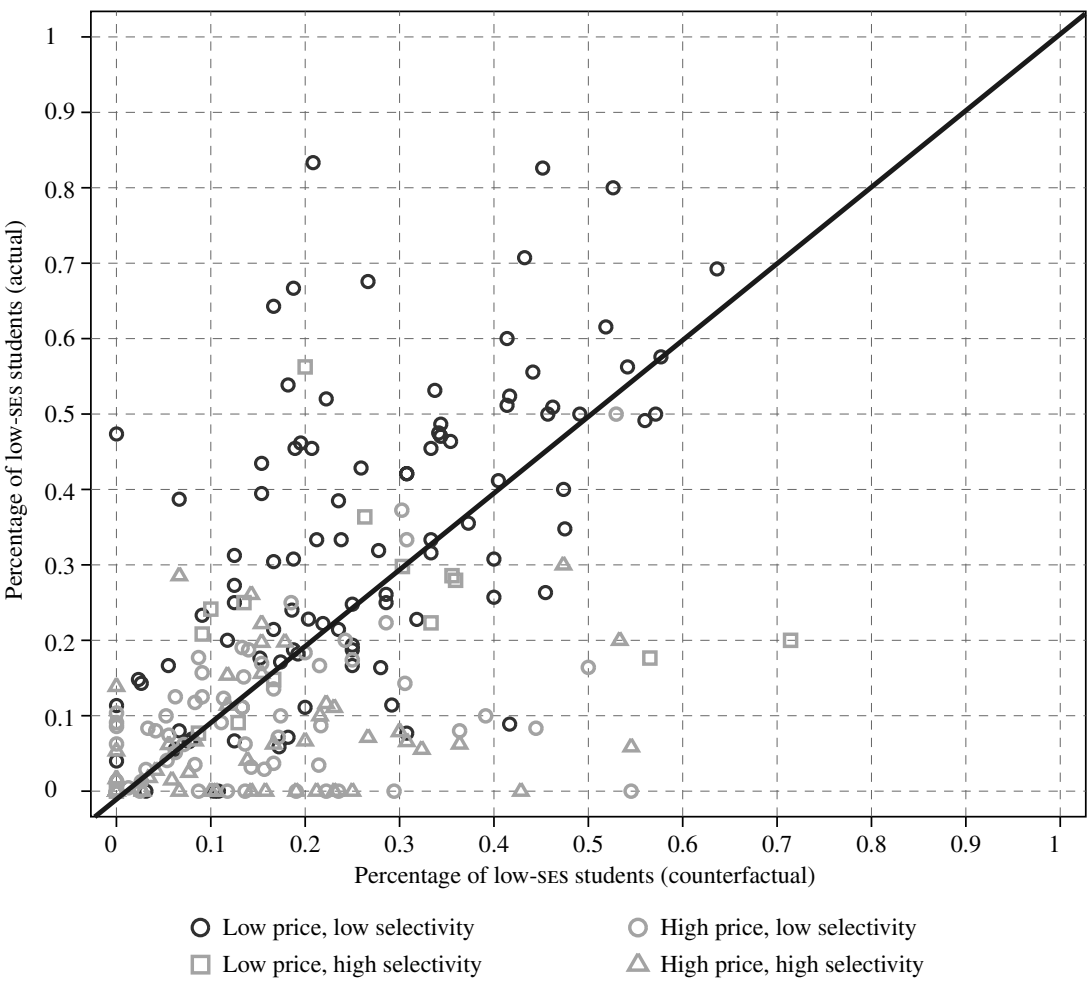

Source: Prepared by the authors.

Note: Analysis is confined to those schools with more than ten students in both scenarios. 
On the one hand, there is a group of schools (the majority of them in the low-selectivity/low-price category) that, similarly to public schools, enrol a greater percentage of low-SEs students than would attend under the counterfactual scenario, suggesting that they likely compete for the same students. On the other hand, there is a set of schools that enrol a smaller percentage of low-
SES students than would attend under the counterfactual scenario. This group consists mostly of schools that charge high tuition and in some cases are very selective (grey triangles). These results are consistent with other studies that find that the for-profit sector tends to seek market niches with families of different socioeconomic levels through price differentiation (Elacqua, 2012).

\section{VI}

\section{Conclusions and implications for public policy}

In order to advance the debate about the effects of school choice on socioeconomic segregation, in this article we use a unique and detailed data set with student and school addresses in the Greater Metropolitan Area of Santiago to compare actual school segregation with the segregation that would occur in the hypothetical case that students attended the school closest to their place of residence.

Consistent with earlier studies in other countries, the results indicate that regardless of the index used, school segregation is greater in the actual scenario than in the counterfactual one. This indicates that schools are more segregated than neighbourhoods and suggests that the interaction between family preferences and the entry barriers established by schools increases school segregation beyond the effect of residential segregation. This finding contradicts the argument that the concentration of students from a similar socioeconomic level is simply a reflection of the residential segregation that exists in Santiago. Our findings demonstrate that there are schools whose social composition is very different from that of the neighbourhood where they are located.

The lower segregation levels seen in the counterfactual scenario can be explained by two complementary effects. First, if students attended the school closest to their residence, segregation would decrease between the public and non-profit sectors. This contradicts the argument of some non-profit school owners - mainly Catholic schools - who argue that their lower disadvantaged student enrolment is a result of the rising socioeconomic level of the neighbourhoods where they have been historically located (Elacqua, 2012). In practice, the majority of these schools behave very similarly to what school choice critics predict for profit-seeking schools, inasmuch as they establish entry barriers that exclude low-SES families, even in socioeconomically diverse neighbourhoods. This finding is not limited to the Chilean education system. In the United States, for example, there are several studies that find that competitive pressure leads non-profit schools (and even some public schools) to use location and admission strategies that exclude the most disadvantaged students (see Lubienski, Gulosino and Weitzel, 2009; Miron, Urschel and Mathis, 2010).

Second, the results indicate that school segregation within the for-profit and non-profit sectors would decline if student distribution were based exclusively on place of residence. This implies that parental preferences and the entry barriers applied by schools increase the concentration of students from a similar socioeconomic level beyond what can be explained by the schools' location and residential segregation. The even lower levels seen in the non-profit sector are explained by the high percentage of schools of this type that combine high prices with selective admission procedures. However, the for-profit sector is almost three times the size of the non-profit sector, thus any changes made in the for-profit sector would have a greater impact on overall segregation.

The challenge in terms of developing policies to promote a more equal distribution of students is that school segregation is the equilibrium result of individual decisions made by various agents (families and schools) who probably do not internalize the aggregate effects of their actions. From this perspective, segregation is a market failure that justifies government action. Although it is not one of the objectives of this article, determining how much of this result is attributable to parent preferences and how much to strategic decisions by schools is key for designing public policies to reduce segregation.

On the supply side, the use of entry barriers to schools is clearly incompatible with parental choice and school vouchers. In other countries with similar programmes, such as the Netherlands, Belgium and Sweden, subsidized education (public and private) is free and schools are prohibited from selecting their students. Therefore, in 
order to guarantee a system where parents have true freedom of choice, such restrictions should be banned. This assertion is supported by recent studies that find that much of school segregation in Chile is explained by the supply side (Flores and Carrasco, 2013; Arteaga, Paredes and Paredes, 2014). For example, Flores and Carrasco (2013) find that the preferences exercised by parents depend on the choice restrictions they face, mainly the price of local schools, and that differences in quality-based preferences between parents of different socioeconomic levels diminish when such restrictions are considered (also see Elacqua, Buckley and Schneider, 2006). In fact, supply-oriented public policies would have lower implementation costs than those that restrict families' school options, since parental choice is perceived as a right by many stakeholders and has long been a feature of the Chilean education system (Aedo, 2000). However, on the demand side, it is important to improve the quantity and quality of information available to families, which is a factor that also likely drives school segregation beyond the differences in preferences between families from different SES groups. Most school choice systems around the world have information systems in place to support families.

The fundamental question then is how to effectively ban entry barriers. On the one hand, school tuition fees could be gradually eliminated. Compared with other OECD countries, per-student spending is still low in Chile, despite a steady rise over the last 20 years. Therefore, the challenge is to gradually replace the private resources contributed by families while keeping resources targeted on the most disadvantaged students. This proposal is consistent with a legislative initiative recently enacted by Chile's Congress (Oficio No. 11.712, 2015). ${ }^{17}$ In

17 Of course, the social impact of this policy should consider that public resources invested have an opportunity cost (for example, investment in preschool education). terms of the admission process, although the General Education Law (LGE) prohibits selection in primary grades, the evidence presented in this article demonstrates that the use of selection mechanisms continues to be common practice in private voucher schools. Recent research suggests that this is due to lack of enforcement (Carrasco and others, 2014). In response to this problem, the current Administration has decided to create a blind and more centralized system of student admission for subsidized schools (public and private). Under the new system, which will be gradually implemented starting in 2016, families must choose and rank the schools of their choice on a computer platform administered by the Ministry of Education. When schools chosen by families have enough open slots, all students will automatically be admitted. When schools are oversubscribed, they will be required to use a random selection procedure (i.e. lottery) to ensure that there will be no arbitrary selection. This process will give priority to students with siblings already enrolled in the school, disadvantaged children and children of school employees. ${ }^{18}$ The system will also take into account parent preferences in the school assignment process (Oficio No. 11.712, 2015).

Although the characteristics of the Chilean education system do contribute to school segregation, the results of this research indicate that residential segregation in the Greater Metropolitan Area of Santiago also plays a part in limiting the integration of students from different socioeconomic levels. Hence, urban policies can play a fundamental role in reducing school segregation. Equally important are policies aimed at improving access to and the quality of public transportation, since this influences the number of options available to families, especially the most disadvantaged (Asahi, 2014).

\footnotetext{
18 Abdulkadiroğlu and Sönmez (2003) present the economic theory and a review of several United States school districts that have adopted centralized school admission processes.
} 


\section{Bibliography}

Abdulkadiroğlu, A. and T. Sönmez (2003), "School choice: a mechanism design approach", American Economic Review, vol. 93, No. 3, Nashville, Tennessee, American Economic Association.

Aedo, R. (2000), La educación privada en Chile: un estudio históricoanalítico desde el período colonial hasta 1990, Santiago, RIL editores.

Allen, R. (2007), "Allocating pupils to their nearest secondary school: the consequences for social and ability stratification", Urban Studies, vol. 44, No. 4, SAGE.

Alves, F. and others (2012), "The effects of school choice on equity: evidence from Rio de Janeiro and Santiago", paper presented at the meeting of the ISA Research Committee on Social Stratification and Mobility (RC28) "Labor Market and Education Transitions in Uncertain Times", Charlottesville.

Arteaga, F., V. Paredes and R. Paredes (2014), "School segregation in Chile: residence, co-payment, or preferences?", unpublished.

Asahi, K. (2014), "The impact of better school accessibility on student outcomes", SERC Discussion Paper, No. 156, London, Spatial Economics Research Centre, London School of Economics and Political Science [online] http://www.spatialeconomics. ac.uk/textonly/SERC/publications/download/sercdp0156.pdf.

Auguste, S. and J.P. Valenzuela (2004), "Do students benefit from school competition? Evidence from Chile", Ann Arbor, University of Michigan, unpublished.

Bayer, P., F. Ferreira and R. McMillan (2007), “A unified framework for measuring preferences for schools and neighborhoods", Journal of Political Economy, vol. 115, No. 4, Chicago, University of Chicago Press.

Bellei, C. (2010), "Segregación socioeconómica y académica de la educación chilena: magnitud, causas y consecuencias", Santiago, University of Chile, unpublished.

Bellei, C., D. de los Ríos and J.P. Valenzuela (2014), "Socioeconomic school segregation in a market-oriented educational system: the case of Chile", Journal of Education Policy, vol. 29, No. 2, Taylor \& Francis.

Beyer, H. and S. Eyzaguirre (2014), "Fin del financiamiento compartido: análisis del proyecto de ley y propuestas", Puntos de Referencia, No. 374, Santiago, Centre for Public Studies [online] http://www. cepchile.cl/Puntos-de-Referencia_CEP_PDF/pder374_HBeyerSEyzaguirre.pdf.

Bifulco, R., H. Ladd and S. Ross (2009), "Public school choice and integration evidence from Durham, North Carolina", Social Science Research, vol. 38, No. 1, Amsterdam, Elsevier.

Black, S. (1999), "Do better schools matter? Parental valuation of elementary education", Quarterly Journal of Economics, vol. 114, No. 2, Oxford University Press.

Bustos, B., D. Contreras and P. Sepúlveda (2010), "When schools are the ones that choose: the effects of screening in Chile", Social Science Quarterly, vol. 91, No. 5, Wiley.

Carrasco, A. and others (2014), "Selección de estudiantes y desigualdad educacional en Chile: ¿Qué tan coactiva es la regulación que la prohíbe?", Proyecto FONIDE, No. 711286, Santiago, Ministry of Education.

Chamber of Deputies (2015), "Oficio N 131-362. Proyecto de Ley que regula la admisión de los y las estudiantes, elimina el financiamiento compartido y prohíbe el lucro en establecimientos educacionales que reciben aportes del Estado", Santiago.

Crain, R. and J. Strauss (1985), "School Desegregation and Black Occupational Attainments: Results from a Long-Term Experiment", Johns Hopkins University [online] http://eric. ed.gov/?id=ED260170.

Duncan, O.D. and B. Duncan (1955), "A methodological analysis of segregation indexes", American Sociological Review, vol. 20, No. 2 [online] http://www.jstor.org/stable/2088328.

El Mercurio (2013), "Principales errores sobre financiamiento compartido", Santiago, 11 July [online] http://impresa.elmercurio.com.
Elacqua, G. (2012), "The impact of school choice and public policy on segregation: evidence from Chile", International Journal of Educational Development, vol. 32, No. 3, Amsterdam, Elsevier.

Elacqua, G., J. Buckley and M. Schneider (2006), "School choice in Chile: is it class or classroom", Journal of Policy Analysis and Managment, vol. 25, No. 3, Wiley.

Elacqua, G. and R. Fábrega (2004), "El consumidor de la educación: el actor olvidado de la libre elección de escuelas en Chile", Santiago, Partnership for Educational Revitalization in the Americas [online] http://www.uai.cl/images/sitio/docentes/ documentos/consumidor_educacion.pdf.

Elacqua, G., M. Martínez and H. Santos (2015), "Voucher policies and the response of for-profit and religious schools: evidence from Chile", Handbook of International Development and Education, P. Dixon, C. Counihan and S. Humble (eds.), Cheltenham, Edward Elgar.

(2011), "Lucro y educación escolar", Claves de Políticas Públicas, No. 1, Santiago, Institute of Public Policies, Diego Portales University [online] http://www.politicaspublicas.udp. $\mathrm{cl} /$ publicaciones/detalle.tpl?id=285.

Fack, G. and J. Grenet (2010), "When do better schools raise housing prices? Evidence from Paris public and private schools", CEE Discussion Paper, No. 119, London, Centre for the Economics of Education, London School of Economics [online] http://cee. 1se.ac.uk/ceedps/ceedp119.pdf.

Flores, C. and A. Carrasco (2013), "(Des)igualdad de oportunidades para elegir escuela: preferencias, libertad de elección y segregación escolar", Documento de Referencia, No. 2, Espacio Público [online] http://espaciopublico.cl/publicaciones/detalle.tpl?id=8.

Gallego, F. (2002), "Competencia y resultados educativos: teoría y evidencia para Chile", Cuadernos de Economía, vol. 39, No. 118 [online] http://repositorio.uc.cl/xmlui/handle/123456789/4790.

Gallego, F. and A. Hernando (2009), "School choice in Chile: looking at the demand side", Working Paper, No. 356, Santiago, Institute of Economics, Catholic University of Chile [online] http://www. economia.puc.cl/DT? docid=3343.

(2008), "On the determinants and implications of school choice: semi-structural simulations for Chile", Working Paper, No. 343, Santiago, Institute of Economics, Catholic University of Chile [online] http://www.economia.puc.cl/AR?docid=1197.

Gibbons, S. and S. Machin (2006), "Paying for primary schools: supply constraints, school popularity or congestion", The Economic Journal, vol. 116, No. 510, Wiley.

(2003), "Valuing English primary schools", Journal of Urban Economics, vol. 53, No. 2, Amsterdam, Elsevier.

Guryan, J. (2004), "Desegregation and black dropout rates", American Economic Review, vol. 94, No. 4, Nashville, Tennessee, American Economic Association [online] http://www.jstor. org/stable/3592799.

Hanushek, E., J. Kain and S. Rivkin (2009), "New evidence about Brown v. Board of Education: the complex effects of school racial composition on achievement", Journal of Labor Economics, vol. 27, No. 3, Chicago, University of Chicago Press.

(2004), "Why public schools lose teachers", Journal of Human Resources, vol. 39, No. 2, Wisconsin, University of Wisconsin Press.

Hoxby, C. (2002), "The power of peers: how does the makeup of a classroom influence achievement", Education Next, vol. 2, No. 2 [online] http://educationnext.org/the-power-of-peers/.

Hsieh, C. and M. Urquiola (2006), "The effects of generalized school choice on achievement and stratification: evidence from Chile's voucher program", Journal of Public Economics, vol. 90, No. 8-9, Amsterdam, Elsevier.

James, E. (1993), "Why do different countries choose a different public-private mix of educational services?", The Journal of Human Resources, vol. 28, No. 3, University of Wisconsin Press. 
James, D. and K. Taeuber (1985), "Measures of segregation", Sociological Methodology, vol. 15, Wiley [online] http://www. jstor.org/stable/270845.

Kahlenberg, R. (2001), All Together Now: Creating Middle Class Schools through Public School Choice, Washington, D.C., Brookings Institution Press.

Krysan, M. (2002), "Whites who say they'd flee: who are they, and why would they leave?", Demography, vol. 39, No. 4, Springer.

Levin, H.M. (2002), "Potential of for-profit schools for educational reform", Occasional Paper, No. 47, Teachers College, Columbia University [online] http://ncspe.org/publications_files/179 _OP47.pdf

Levinson, M. and S. Levinson (2003), "Getting religion: religion, diversity, and community in public and private schools", School Choice: The Moral Debate, A. Wolfe (ed.), Princeton, Princeton University Press.

Lubienski, C., C. Gulosino and P. Weitzel (2009), "School choice and competitive incentives: mapping the distribution of educational opportunities across local education markets", American Journal of Education, vol. 115, No. 4, Chicago, University of Chicago Press.

Massey, D. and N. Denton (1988), "The dimensions of residential segregation", Social Forces, vol. 67, No. 2, Oxford University Press.

Miron, G., J. Urschel and W. Mathis (2010), Schools without Diversity: Education Management Organizations, Charter Schools, and the Demographic Stratification of the American School System [online] http://nepc.colorado.edu/publication/schoolswithout-diversity.

Moe, T. (2001), "The politics of vouchers", Schools, Vouchers and the American Public, T. Moe (ed.), Washington, D.C., Brookings Institution Press.

OECD (Organization for Economic Cooperation and Development) (2011), Education at a Glance 2011: OECD Indicators, Paris, OECD Publishing.

Östh, J., E. Andersson and B. Malmberg (2013), "School choice and increasing performance difference: a counterfactual approach", Urban Studies, vol. 50, No. 2, SAGE.
Reardon, S. and G. Firebaugh (2002), "Measures of multigroup segregation", Sociological Methodology, vol. 32, No. 1, Wiley.

Reback, R. (2005), "House prices and the provision of local public services: capitalization under school choice programs", Journal of Urban Economics, vol. 57, No. 2, Amsterdam, Elsevier.

Riedel, A. and others (2010), "School choice in German primary schools: how binding are school districts?", Journal for Educational Research Online, vol. 2, No. 1 [online] http://www.j-e-r-o.com/ index.php/jero/article/viewFile/76/65.

Rose-Ackerman, S. (1996), "Altruism, nonprofits, and economic theory", Journal of Economic Literature, vol. 34, No. 2 [online] http://www.jstor.org/stable/2729219.

Rothstein, R. (2004), Class and Schools: Using Social, Economic, and Educational Reform to Close the Black-White Achievement Gap, Washington, D.C., Economic Policy Institute.

Sirin, S. (2005), "Socioeconomic status and academic achievement: a meta-analytic review of research", Review of Educational Research, vol. 75, No. 3, SAGE.

Sohoni, D. and S. Saporito (2009), "Mapping school segregation: using gis to explore racial segregation between schools and their corresponding attendance areas", American Journal of Education, vol. 115, No. 4, Chicago, University of Chicago Press.

Wells, A.S. and others (2008), Both Sides Now: the Story of School Desegregation's Graduates, Berkeley, University of California Press.

White, M.J. (1986), "Segregation and diversity measures in population distribution", Population Index, vol. 52, No. 2, Office of Population Research [online] http://www.jstor.org/stable/3644339.

Zimmer, R.W. and E.F. Toma (2000), "Peer effects in private and public schools across countries", Journal of Policy Analysis and Management, vol. 19, No. 1, Wiley.

Zoloth, B.S. (1976), "Alternative measures of school segregation", Land Economics, vol. 52, No. 3 [online] http://www.jstor.org/ stable/3145527. 